\title{
Thyroid status is related to migratory behavior in Anguilla anguilla glass eels
}

\author{
Eric Edeline $^{1, *}$, Sylvie Dufour ${ }^{2}$, Cédric Briand ${ }^{3}$, Denis Fatin ${ }^{3}$, Pierre Elie ${ }^{1}$ \\ ${ }^{1}$ Cemagref, Unité Resources Aquatiques Continentales, 50 Avenue de Verdun, 33612 Cestas Cedex, France \\ ${ }^{2}$ Muséum National d'Histoire Naturelle, USM 0401, Département 'Milieux et Peuplements Aquatiques', \\ UMR CNRS/MNHN/UPMC 5178 'Biologie des Organismes Marins et Ecosystèmes', Bâtiment de Physiologie, \\ 7 rue Cuvier, 75231 Paris Cedex 05, France \\ ${ }^{3}$ Institution d'Aménagement de la Vilaine, 56130 La Roche Bernard, France
}

\begin{abstract}
To determine whether thyroidal status is related to migratory and settling behavior in Anguilla anguilla glass eels, we sampled glass eels showing different migratory behaviors in the Arzal dam, which constitutes the tidal limit of the Vilaine River (France). We collected 4 groups of glass eels: flood and ebb tide glass eels were netted in the estuary during the flood and ebb tides, respectively, trap glass eels were sampled from the eel ladder trap, and bottom glass eels sheltering on the bottom of the estuary during flood tide. We measured individual whole-body triiodothyronine $\left(\mathrm{T}_{3}\right)$ and thyroxine $\left(\mathrm{T}_{4}\right)$ levels for these groups, and calculated total thyroid hormone (TH) levels as $\mathrm{T}_{3}+\mathrm{T}_{4}$ contents reflecting the thyroid gland secretory activity, and $\mathrm{T}_{3}: \mathrm{T}_{4}$ ratios reflecting $\mathrm{T}_{4}$ outer-ring desiodase $\left(\mathrm{T}_{4} \mathrm{ORD}\right.$ ) activity. Trap glass eels had the highest TH levels, indicating an activation of the thyroid gland via the thyreotrop axis. This could be responsible for the behavioral transition (loss of circatidal rhythm and switch to counter-current swimming) at the tidal limit and active colonization of river habitats by glass eels. Ebb and flood tide glass eels had similar TH levels that were lower than those of trap glass eels, indicating a lower thyroid gland secretory activity in the former. Ebb tide glass eels had higher $T_{3}: T_{4}$ ratios than flood tide and trap glass eels, indicating physiological stress related to inefficient use of tidal streams. Bottom glass eels had the lowest TH levels, and high $\mathrm{T}_{3}: \mathrm{T}_{4}$ ratios similar to those of ebb tide glass eels; this suggests that physiological stress induced by frequent counter-current swimming leads to precocious settlement of glass eels in estuarine habitats. Our data supports the critical role of the thyroid status in the migratory and settling behavior of glass eels in estuarine and marine habitats.
\end{abstract}

KEY WORDS: Glass eel · Migration - Settlement · Habitat colonization · Thyroid gland activity · Selective tidal stream transport

Resale or republication not permitted without written consent of the publisher

\section{INTRODUCTION}

At the end of their transoceanic migration, Anguilla anguilla leptocephalus larvae metamorphose into glass eels off the continental shelf of Europe (Schmidt 1909), and subsequently colonize continental waters. Within estuaries, they use selective tidal stream transport (STST) for upstream movement (Creutzberg 1961, Elie 1979, McCleave \& Kleckner 1982, Gascuel 1986, McCleave \& Wippelhauser 1987). To do so, glass eels remain on or near to the bottom during ebb tide and move up into the water column on flood tide, timing their sojourn by an internal clock (Wippelhauser \& McCleave 1987, 1988). This mechanism enables rapid landward transport of the glass eels at low energetic cost (Weihs 1978, Metcalfe et al. 1990). At the tidal limit of the river, glass eels show a pronounced change in migratory behavior (Gascuel 1986, McCleave \& Wippelhauser 1987) involving loss of the circatidal rhythm and acquisition of a strictly counter-current swimming behavior. This may involve a migration delay at the tidal limit (McCleave \& Wippelhauser 
1987). The mechanisms that regulate this behavioral transition are unknown. Moreover, some individuals never colonize freshwater; they settle in estuaries or along the coastline (Tsukamoto \& Arai 2001, Tzeng et al. 2003) and do not even reach the tidal limit. The internal factors leading to this divergent migratory behavior are also unknown.

In teleosts, thyroid hormones (THs), L-thyroxine $\left(\mathrm{T}_{4}\right)$ and 3,5,3'-triiodo-L-thyronine $\left(\mathrm{T}_{3}\right)$, are involved in a wide range of biological processes such as development, growth, reproduction, osmoregulation, ionic regulation (Eales 1979, Eales \& Brown 1993) and probably also metabolism (Woodhead 1975). Further, THs have been linked to migratory and homing behavior in many fish species (Fontaine 1975, Woodhead 1975, Comeau et al. 2001). In teleosts, production of $\mathrm{T}_{4}$, the main hormone secreted by the thyroid gland, is regulated by the hypothalamo-pituitary axis via the thyroid stimulating hormone (TSH) (Fig. 1). $\mathrm{T}_{4}$ is released into the blood and deiodinated by $\mathrm{T}_{4}$ outer-ring deiodases $\left(\mathrm{T}_{4}\right.$ ORD) into $\mathrm{T}_{3}$ in the peripheral tissues. Subsequently, $T_{3}$ is deiodinated to the biologically inactive 3,3 ' diiodo-L-thyronine $\left(\mathrm{T}_{2}\right)$ by $\mathrm{T}_{3}$ inner-ring deiodases $\left(\mathrm{T}_{3}\right.$ IRD) or excreted through urine or bile (Fig. 1). The binding affinity of $\mathrm{T}_{3}$ to $\mathrm{TH}$ receptors is approximately 10 -fold higher than $\mathrm{T}_{4}$, as shown in the hepatocytes of Salmo gairdneri and Oncorhynchus kisutch (Darling et al. 1982, Bres \& Eales 1986).

In the American eel Anguilla rostrata at the yellow stage, migrating individuals caught climbing waterfalls exhibited higher plasma $\mathrm{T}_{4}$ levels than individuals caught below the waterfalls (Castonguay et al. 1990). In young salmon, the $\mathrm{T}_{4}$ surge associated with smoltifi-

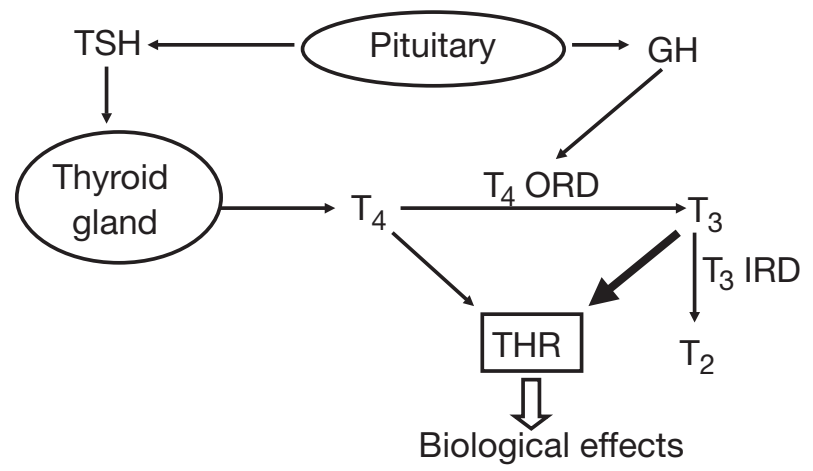

Fig. 1. General thyroid model. Thyroid stimulating hormone (TSH) produced by pituitary gland regulates thyroid synthesis and secretion of L-thyroxine $\left(\mathrm{T}_{4}\right) . \mathrm{T}_{4}$ is released into blood and deiodinated in 3,5,3'-triiodo-L-thyronine $\left(\mathrm{T}_{3}\right)$ in peripheral tissues by $\mathrm{T}_{4}$ outer-ring deiodases $\left(\mathrm{T}_{4} \mathrm{ORD}\right.$ ). Pituitary growth hormone $(\mathrm{GH})$ stimulates activity of $\mathrm{T}_{4}$ ORD. $\mathrm{T}_{3}$ binds thyroid hormone receptors (THR) with higher affinity than $\mathrm{T}_{4}$. $\mathrm{T}_{3}$ can be deiodinated by $\mathrm{T}_{3}$ inner-ring deiodinases ( $\mathrm{T}_{3}$ IRD) in $3,3^{\prime}$ diiodo-L-thyronine $\left(\mathrm{T}_{2}\right)$, which is ineffective in stimulating THR cation induces a change in their rheotactic behavior (Iwata 1995, Specker et al. 2000, Iwata et al. 2003). During development of the red sea bream Pagrus major and the metamorphosis of the summer flounder Paralichthys dentatus, a $\mathrm{T}_{4}$ surge may promote the transition from pelagic toward settling behavior (Hirata et al. 1989, Schreiber \& Specker 1999). In glass eels, a role of THs in rheotropism and in the capacity to migrate away from the sea has been hypothesized (Fontaine \& Callamand 1941, Fontaine 1975). More recently, a correlation between decreasing $\mathrm{T}_{4}$ levels and the transition from pelagic toward benthic behavior was shown in glass eels $A$. anguilla held in an aquarium (Jegstrup \& Rosenkilde 2003).

As a first step to understanding the potential internal mechanisms controlling migration and habitat colonization, we measured $\mathrm{TH}\left(\mathrm{T}_{3}\right.$ and $\left.\mathrm{T}_{4}\right)$ levels in Anguilla anguilla glass eels exhibiting different migratory behavior under natural conditions. The ecological implications of our findings are discussed.

\section{MATERIALS AND METHODS}

Sampling site. Glass eels were sampled during April 2003 in the Vilaine River estuary in South Brittany, France $\left(1^{\circ} 5^{\prime} \mathrm{W}, 45^{\circ} 5^{\prime} \mathrm{N}\right.$, Fig. 2). The Arzal estuarine dam, equipped with an eel ladder, is located $12 \mathrm{~km}$ from the mouth of the estuary and constitutes the tidal limit. The eel ladder consists of 2 ramps lined with tufts of synthetic brushes (described by Legault 1992). These ramps lead to a central canal and onto a second ramp, from which glass eels fall into a holding tank constituting a trap that is cleared daily (Briand et al. 2002). Water flowing over the eel ladder is freshwater from the pond created by the dam. Climbing takes place at night, and glass eels are able to climb the entire ladder within 1 or $2 \mathrm{~h}$. Water depth below the dam ranges from 5 to $11 \mathrm{~m}$ and salinity from 0 to $25 \mathrm{psu}$ depending on tide and river discharge.

Sampling. We collected 4 groups of glass eels, classified according to place of capture and tidal conditions: 'trap glass eels' were sampled from the eel ladder trap after they had climbed the 2 ramps; 'flood-tide glass eels' and 'ebb tide glass eels' were netted from the estuary in a fishing boat, $100 \mathrm{~m}$ below the dam during flood and ebb tides respectively; 'bottom glass eels' were sampled from collectors on the estuary bottom during flood tide. Collectors consist of polyethylenethread tufts inserted into a heavy $50 \times 60 \times 10 \mathrm{~cm}$ PVC base to represent artificial vegetation (Silberschneider et al. 2001). Although as many as 9 collectors were used, only 5 bottom glass eels were caught and analyzed for TH content. A subsample from each of the other 3 groups was kept for analysis of pigment stages 
or for $\mathrm{TH}$ level assessment. Details are presented in Table 1. Glass eels were collected during either full moon or during its last quarter. Lunar phase may influence the migration of glass eels by means of both tides and moonlight (Jellyman \& Lambert 2003); however, it does not affect glass eel migration in the Vilaine River estuary (C. Briand unpubl. data). This may be due to the high turbidity of the estuary waters hindering penetration of moonlight through the water column, and/or to the proximity of the dam to the sea, which has a strong tidal influence below the dam even during neap tides.

Sample storage. Glass eels were dried on blotting paper, individually stored in cryotubes that had been previously weighted to the nearest $10^{-4} \mathrm{~g}$, and then frozen in liquid nitrogen vats. The fresh weight of the glass eels could thus be obtained without thawing, by weighing the cryotube containing the glass eel and subtracting the weight of the tube. Samples were stored at $-20^{\circ} \mathrm{C}$ until extraction. Glass eels used for pigment-stage analysis were put into bags and frozen at $-20^{\circ} \mathrm{C}$.

Determination of pigment stages. After thawing, the glass eels were examined microscopically to determine pigment stage according to Elie et al. (1982). Briefly, pigment stages describe the extent of skin pigmentation over the head, tail and body regions through Stages VA, VB, VIA $, \mathrm{VIA}_{1}, \mathrm{VIA}_{2}, \mathrm{VIA}_{3}$ and $\mathrm{VIA}_{4}$ to VIB. The distinction between glass eel and elver stages is unclear (Tabeta \& Mochioka 2003). In this paper, we use the term 'glass eel' for all pigment stages between Stages VA and VIB.

Radio immunoassay (RIA). The method followed was that of Cis Bio International for total $T_{4}$ and total $T_{3}$ (RIA) kits (Gif s/Yvette), using tubes coated with anti$\mathrm{T}_{3}$ or $\mathrm{T}_{4}$ antibodies and ${ }^{125} \mathrm{I}$ radiolabelled $\mathrm{T}_{3}$ or $\mathrm{T}_{4}$. Sensitivity was $0.1 \mathrm{ng} \mathrm{ml} \mathrm{m}^{-1}$ for $\mathrm{T}_{3}$ and $2.5 \mathrm{ng} \mathrm{ml}^{-1}$ for $\mathrm{T}_{4}$. Briefly, after addition of the extract or standard and radiolabelled hormone to antiserum-coated tubes, the tubes were incubated at $37^{\circ} \mathrm{C}$ for $2 \mathrm{~h}$ and then decanted. The radioactive fraction bounded to the tube

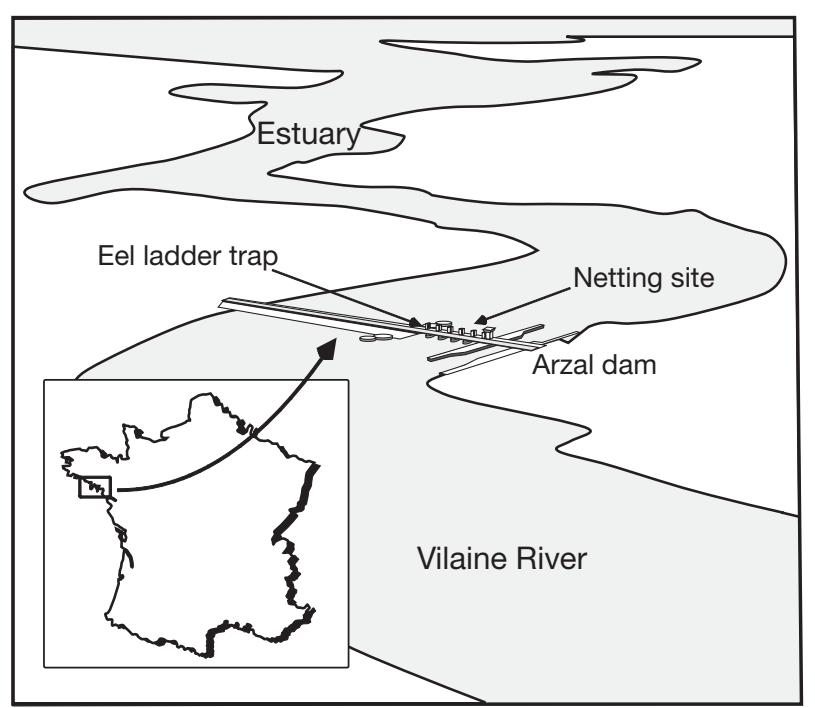

Fig. 2. Map of France (inset) showing location of Vilaine River estuary. Details of Arzal dam with locations of eel ladder trap and netting site in estuary where glass eels Anguilla anguilla were sampled are shown

was counted in a gamma counter (MDA 312, Kontron Analytical). The bounded radioactive fraction $(B)$ is expressed as a percentage of the maximal bounded radioactive fraction $\left(B_{0}\right)$ which was measured without the addition of cold $\mathrm{TH}$ to the antiserum-coated tube. Percentage $B: B_{0}$ was inversely proportional to the amount of cold $\mathrm{TH}$ in samples, which was calculated from the standard dilution-curve parameters. Individual whole-body $T_{3}$ and $T_{4}$ levels were measured in duplicate in both assays and expressed as ng hormone $\mathrm{g}^{-1}$ wet body mass. Total thyroid hormone (TH) content was calculated as $\mathrm{T}_{3}$ content $+\mathrm{T}_{4}$ content for each individual. Similarly, the ratio $T_{3}: T_{4}$ was also calculated for each individual.

Pilot experiments. Pilot experiments were conducted to determine the best extraction medium and the volume of glass eel extract necessary to work

Table 1. Anguilla anguilla. Characteristics of glass eel groups used for measurement of whole-body thyroid hormones levels and pigment stages. Groups: Ebb, sampled by netting at ebb tide; Flood, sampled by netting at flood tide; Trap, sampled from eel ladder trap; Bottom, sampled from collectors on bottom of estuary at flood tide. All samples collected during night in April 2003 (midcolumn = mid-water column; bottom = bottom of estuary water column); $T$ : water temperature; N TH: no. analyzed for thyroid hormone; $\mathrm{N}$ stage: no. analyzed for pigment stage

\begin{tabular}{|c|c|c|c|c|c|c|c|c|}
\hline \multirow[t]{2}{*}{ Group } & \multicolumn{3}{|c|}{ —Sampling } & \multirow[t]{2}{*}{ Tide, moon phase } & \multirow{2}{*}{$\begin{array}{c}T \\
\left({ }^{\circ} \mathrm{C}\right)\end{array}$} & \multirow{2}{*}{$\begin{array}{l}\text { Salinity } \\
\text { (psu) }\end{array}$} & \multirow{2}{*}{$\begin{array}{l}\mathrm{N} \\
\mathrm{TH}\end{array}$} & \multirow{2}{*}{$\begin{array}{c}\mathrm{N} \\
\text { stage }\end{array}$} \\
\hline & Gear & Date & Location & & & & & \\
\hline Ebb & Net & 23 Apr & Estuary, mid-column & Ebb, last quarter & 14 & 21 & 46 & 74 \\
\hline Flood & Net & 16 Apr & Estuary, mid-column & Flood, full moon & 12 & 20 & 114 & 62 \\
\hline Trap & Ladder trap & 16 Apr & Eel ladder & Flood, full moon & 12 & 0 & 69 & 18 \\
\hline Bottom & Collector & $23 \mathrm{Apr}$ & Bottom & Flood, last quarter & 14 & 21 & 5 & 0 \\
\hline
\end{tabular}


within the sensitivity range of the RIA kits. We used pools of extracts of 5 to 8 glass eels from the Dordogne River (France) caught in 2002. The extraction method is described below. We tested 4 different extraction media: $0.01 \mathrm{M}$ phosphate-buffer saline, $\mathrm{pH}$ 7.4 (PBS); phosphate-buffer saline, $\mathrm{pH} 7.4$, containing $1 \mathrm{mM}$ 5-propyl-2-thiouracil (Sigma) (PBS-PTU); absolute ethanol (EtOH) and absolute ethanol containing $1 \mathrm{mM}$ PTU (EtOH-PTU). PTU was used to block endogenous desiodase activity (Denver 1993). This pilot experiment showed that the most efficient extraction medium was EtOH-PTU. Details are presented in 'Results'.

Extraction. The extraction procedure chosen was similar to that of Tagawa \& Hirano (1987), with minor modifications. Extraction was made in cryotubes in ice-cold EtOH-PTU. Homogenization was carried out using an Ultra-Turrax homogenizer (Labo Moderne, Paris) and followed by sonication for $20 \mathrm{~s}$ with a Vibra
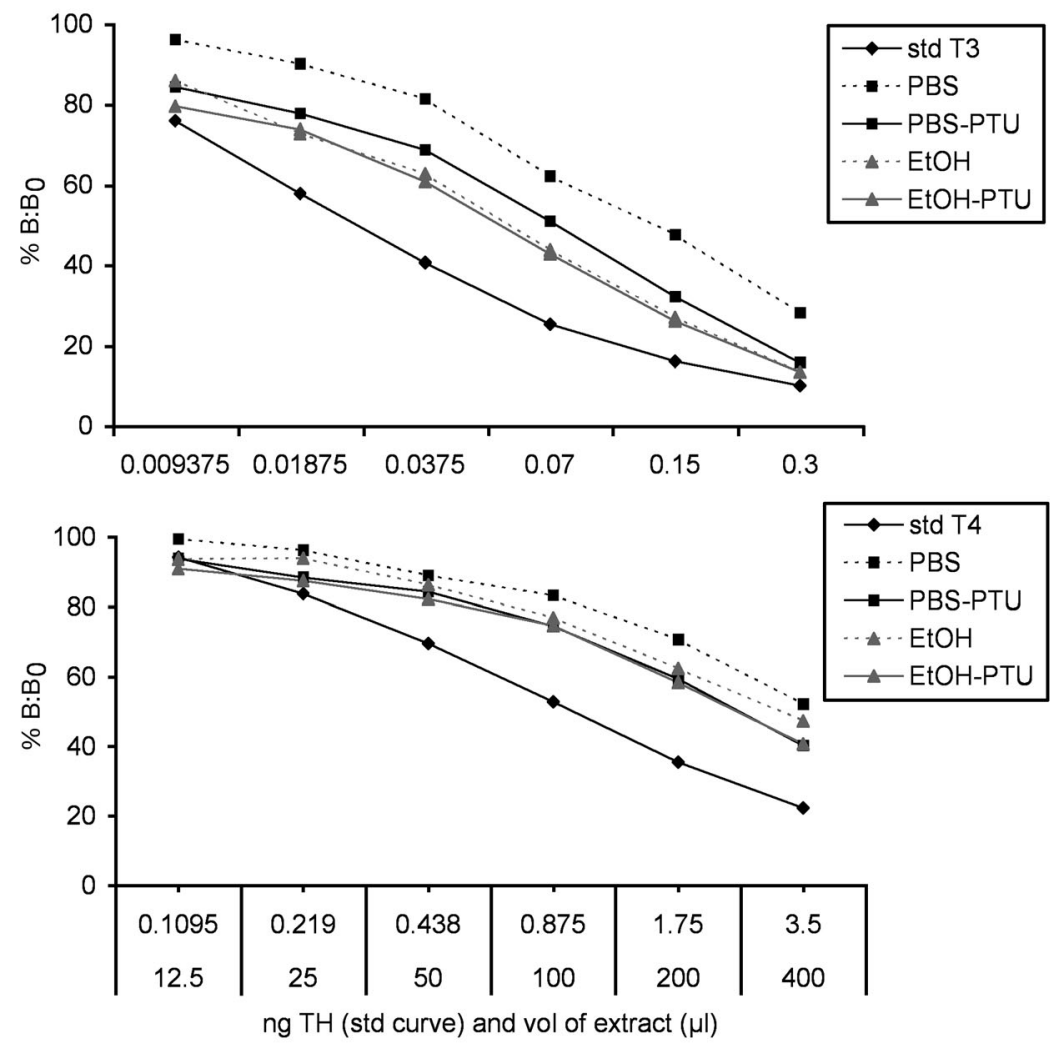

Fig. 3. Anguilla anguilla. Dose-response curves of glass eel extracts in radio immunoassays (RIAs) for thyroid hormones (THs) $\mathrm{T}_{3}$ and $\mathrm{T}_{4}$. RIA competitive binding curves are expressed as percentage of maximal binding of radiotracer $\left(\% B: B_{0}\right)$ for serial dilutions of $\mathrm{T}_{3}$ and $\mathrm{T}_{4}$ standards (std) and glass eel extracts. Each point represents average of duplicates. Note that for both hormones, curves for serial dilutions of extracts are parallel to curve for serial dilutions of standard. PBS: phosphate buffer saline; PBS-PTU: phosphate buffer saline containing $1 \mathrm{mM}$ 5-propyl-2-thiouracil; EtOH: absolute ethanol; EtOH-PTU: absolute ethanol containing $1 \mathrm{mM}$ 5-propyl-2-thiouracil
Cell 72434 sonicator (Bioblock Scientific). The blades of the homogenizer were rinsed with $0.3 \mathrm{ml}$ ice-cold EtOH-PTU and the rinse was added to the homogenate. After centrifugation at $2950 \times g$ for $20 \mathrm{~min}$ at $4^{\circ} \mathrm{C}$, the supernatant was kept and the pellet was reextracted in $0.3 \mathrm{ml}$ ice-cold EtOH-PTU by $20 \mathrm{~s}$ sonication. After a second centrifugation, both supernatants were pooled and centrifugated at $64 \times g$ for min at $4^{\circ} \mathrm{C}$. The supernatant was vacuum-dried at for $24 \mathrm{~h}$ in a SVC $100 \mathrm{H}$ SpeedVac (Savant). ples were reconstituted by sonication in $800 \mu \mathrm{l}$ content by RIA.

Statistics. For analysis of pigment-stage differences between groups with a $\chi^{2}$-test (SYSTAT), we pooled pigment stages into 3 pools $\left(\mathrm{VB}, \mathrm{VIA}_{0}\right.$ and $\mathrm{VIA}_{1}$ and more) to avoid pools of less than 5 individuals. For validation of extraction procedures, after log-linearization, parallelism of dilution curves of extract with the standard dilution curve in the RIA were tested with an ANCOVA (SYSTAT). $\mathrm{T}_{3}$, $\mathrm{T}_{4}, \mathrm{TH}, \mathrm{T}_{3}: \mathrm{T}_{4}$ ratio levels and mass distribution differences between groups were tested with a Kolmogorov-Smirnov test (2sample KS, SYSTAT). Results are given as means $\pm \mathrm{SD}$.

\section{RESULTS}

\section{Pilot extraction experiments}

Serial dilutions of tissue extracts inhibited the binding of $\mathrm{TH}$ radiotracer, to produce a dose-response curve parallel to that of the $\mathrm{TH}$ standard $\left(\mathrm{p}=0.483\right.$ for $\mathrm{T}_{3}$, $\mathrm{p}=0.959$ for $\mathrm{T}_{4}$, ANCOVA). This was obtained with the 4 extraction media (Fig. 3). The extraction efficiency was EtOH-PTU $>$ EtOH $>$ PBS-PTU $>$ PBS for $\mathrm{T}_{3}$ and EtOH-PTU $\geq \mathrm{PBS}-\mathrm{PTU}>\mathrm{EtOH}>$ PBS for $\mathrm{T}_{4}$ (Fig. 3). For the subsequent study of individual whole-body $\mathrm{TH}$, we therefore chose the extraction medium providing the best efficiency, i.e. EtOHPTU. Extract volumes for individual samples which corresponded to the linear parts of the standard dilution curves were $75 \mu \mathrm{l}$ for $\mathrm{T}_{3}$ and $200 \mu \mathrm{l}$ for $\mathrm{T}_{4}$.

\section{Body mass and pigment stages}

Ebb tide glass eels $(0.286 \pm 0.057 \mathrm{~g})$ had significantly smaller masses than trap 
Table 2. Anguilla anguilla. Mean body mass and pigment stages (after Elie et al. 1982) for each glass eel group. -: no data. Collection details in Table 1

\begin{tabular}{|c|c|c|c|c|c|c|c|c|c|}
\hline \multirow[t]{2}{*}{ Glass eel groups } & \multicolumn{2}{|c|}{ Body mass $(\mathrm{g})$} & \multicolumn{7}{|c|}{ —Pigment stage $(\%)$} \\
\hline & Mean \pm SD & Range & VB & VIA $_{0}$ & $\mathrm{VIA}_{1}$ & $\mathrm{VIA}_{2}$ & $\mathrm{VIA}_{3}$ & $\mathrm{VIA}_{4}$ & VIB \\
\hline Ebb & $0.286 \pm 0.057$ & $0.175-0.441$ & 77 & 14 & 2 & 5 & 2 & 0 & 0 \\
\hline Flood & $0.302 \pm 0.056$ & $0.182-0.522$ & 73 & 18 & 8 & 1 & 0 & 0 & 0 \\
\hline Trap & $0.304 \pm 0.048$ & $0.213-0.425$ & 0 & 11 & 17 & 33 & 17 & 22 & 0 \\
\hline Bottom & $0.291 \pm 0.062$ & $0.221-0.356$ & - & - & - & - & - & - & - \\
\hline
\end{tabular}

glass eels $(0.304 \pm 0.048 \mathrm{~g})(\mathrm{p}<0.05, \mathrm{KS})$, but masses were not significantly different between any other combination of groups ( $\mathrm{p}>0.227, \mathrm{KS})$ (Table 2). Pigment stages of trap glass eels were more advanced than those of ebb and flood tide glass eels $(p<0.001$, $\chi^{2}$ ) but were not significantly different between ebb tide and flood tide glass eels ( $p>0.8, \chi^{2}$ ) (Table 2).

\section{$T_{3}$ content}

Whole-body $\mathrm{T}_{3}$ levels were $1.70 \pm 0.26 \mathrm{ng} \mathrm{g}^{-1}$ in bottom glass eels, $1.79 \pm 0.38 \mathrm{ng} \mathrm{g}^{-1}$ in ebb tide glass eels, $1.50 \pm 0.43 \mathrm{ng} \mathrm{g}^{-1}$ in flood tide glass eels and $1.79 \pm 0.44 \mathrm{ng} \mathrm{g}^{-1}$ in trap glass eels (Fig. 4). Wholebody $\mathrm{T}_{3}$ levels were not significantly different between trap, ebb tide and bottom glass eels, but were significantly lower in flood tide glass eels than in ebb tide $(\mathrm{p}<0.001, \mathrm{KS})$ and trap $(\mathrm{p}<0.003, \mathrm{KS})$ glass eels. Moreover, whole-body $\mathrm{T}_{3}$ levels were not significantly different between bottom and flood tide glass eels $(\mathrm{p}>0.2, \mathrm{KS})$.

\section{$\mathrm{T}_{4}$ content}

Whole-body $\mathrm{T}_{4}$ levels were $10.41 \pm$ $0.9 \mathrm{ng} \mathrm{g}^{-1}$ in bottom glass eels, $13.02 \pm$ $4.01 \mathrm{ng} \mathrm{g}^{-1}$ in ebb tide glass eels, $14.23 \pm 4.18 \mathrm{ng} \mathrm{g}^{-1}$ in flood tide glass eels and $16.24 \pm 3.85 \mathrm{ng} \mathrm{g}^{-1}$ in trap glass eels (Fig. 4). Whole-body $\mathrm{T}_{4}$ levels were not significantly different between bottom and ebb tide glass eels ( $\mathrm{p}>0.05 ; \mathrm{KS}$ ). When compared to flood tide glass eels, bottom and ebb tide glass eels had significantly lower whole-body $\mathrm{T}_{4}$ levels ( $\mathrm{p}<0.008$ and $\mathrm{p}<0.05, \mathrm{KS}$, respectively). Moreover, whole-body $\mathrm{T}_{4}$ levels of flood tide glass eels where significantly lower than those of trap glass eels ( $\mathrm{p}<$ $0.005, \mathrm{KS})$.

\section{TH content $\left(T_{3}+T_{4}\right)$}

Whole-body $\mathrm{TH}\left(\mathrm{T}_{3}+\mathrm{T}_{4}\right)$ content was $12.12 \pm 1.12 \mathrm{ng}$ $\mathrm{g}^{-1}$ in bottom glass eels, $14.81 \pm 4.19$ in ebb tide glass eels, $15.73 \pm 4.44 \mathrm{ng} \mathrm{g}^{-1}$ in flood tide glass eels and $18.04 \pm 4.02 \mathrm{ng} \mathrm{g}^{-1}$ in trap glass eels (Fig. 5). Wholebody $\mathrm{TH}$ levels were not significantly different between bottom and ebb tide glass eels ( $p>0.07, \mathrm{KS})$ and between flood and ebb tide glass eels ( $p>0.05, K S)$, but were significantly higher in flood tide than in bottom glass eels ( $p<0.05, \mathrm{KS})$ and significantly higher in trap glass eels than in flood tide glass eels $(p<0.002, K S)$.

\section{$\mathrm{T}_{3}: \mathrm{T}_{4}$ ratio}

$\mathrm{T}_{3}: \mathrm{T}_{4}$ ratios were $0.16 \pm 0.02$ for bottom glass eels, $0.14 \pm 0.04$ for ebb tide glass eels, $0.11 \pm 0.03$ for flood tide glass eels and $0.11 \pm 0.03$ for trap glass eels (Fig. 5). $T_{3}: T_{4}$ ratios were not significantly different between bottom and ebb tide glass eels (KS, p > 0.1) and between trap and flood tide glass eels (KS, $\mathrm{p}>0.4$ ) but were significantly higher in bottom and ebb tide glass eels than in trap and flood tide and trap glass eels (KS, p < 0.002).
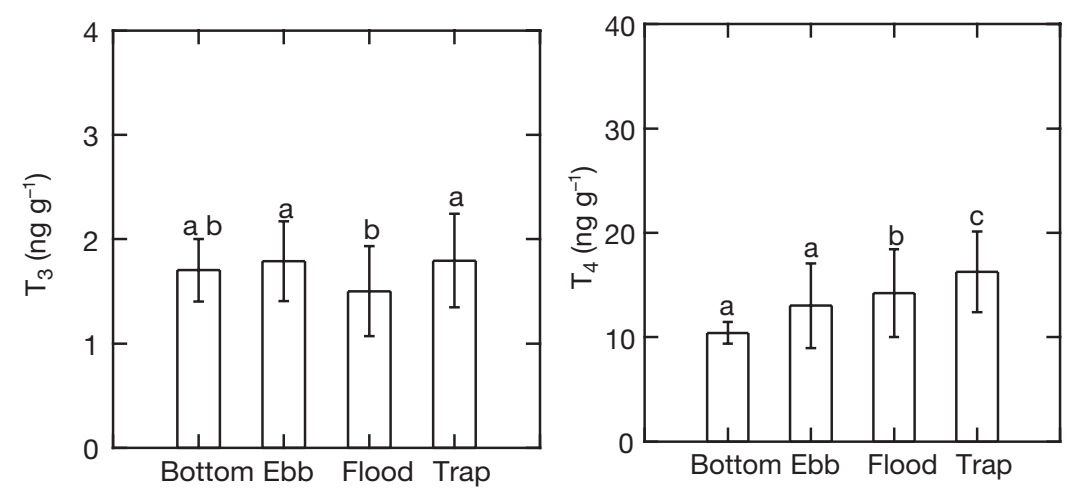

Fig. 4. Anguilla anguilla. Mean $( \pm \mathrm{SD})$ whole-body $\mathrm{T}_{3}$ and $\mathrm{T}_{4}$ levels (ng hormone $\mathrm{g}^{-1}$ wet body mass) measured in glass eels by RIA. Bottom: bottom glass eels $(N=5)$, ebb: ebb tide glass eels $(N=46)$, flood: flood tide glass eels $(N=114)$, trap: trap glass eels $(N=69)$. Different letters above bars indicate significant differences between distributions ( $p<0.05$, Kolmogorov-Smirnov test) 

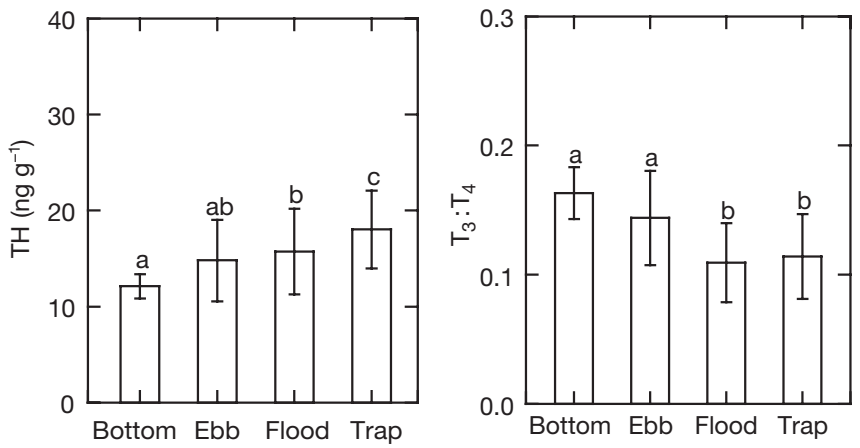

Fig. 5. Anguilla anguilla. Mean $( \pm \mathrm{SD})$ whole-body $\mathrm{TH}$ $\left(\mathrm{T}_{3}+\mathrm{T}_{4}\right.$ ) levels (ng hormone $\mathrm{g}^{-1}$ wet body mass) and $\mathrm{T}_{3}: \mathrm{T}_{4}$ level ratios for glass eels. Further details as in Fig. 4

\section{DISCUSSION}

In this study, we compared differences in wholebody $\mathrm{TH}$ levels between glass eels showing different migratory behaviors at the tidal limit with the aim of determining whether and how these hormones could be implicated in migration and settlement phenomena.

\section{Extraction}

Comparison of different extraction media showed that the best extraction efficiency was obtained with EtOHPTU, with PTU blocking the action of deiodases (Denver 1993). Our results show that in Anguilla anguilla glass eels, $\mathrm{T}_{4}$ content is approximately 10 -fold that of $\mathrm{T}_{3}$. Since the binding affinity of $\mathrm{T}_{3}$ to $\mathrm{TH}$ receptors is approximately 10-fold higher than that of $\mathrm{T}_{4}$ (Darling et al. 1982, Bres \& Eales 1986), this suggests that in A. anguilla glass eels, $\mathrm{T}_{3}$ and $\mathrm{T}_{4}$ may contribute to $\mathrm{TH}$ receptor stimulation in the same order of magnitude. Whole-body $\mathrm{T}_{3}$ and $\mathrm{T}_{4}$ levels ( 1.5 to 1.79 and 10 to $16 \mathrm{ng} \mathrm{g}^{-1}$, respectively) were similar to those in metamorphosing Conger myriaster leptocephalus larvae ( 0.15 to 2 and 5 to $30 \mathrm{ng} \mathrm{g}^{-1}$, respectively) (Yamano et al. 1991) and of the same magnitude as those in salmonid fry (Tagawa \& Hirano 1987, Greenblatt et al. 1989).

\section{Body mass and pigment stages}

The body mass of trap glass eels was slightly but significantly larger than that of ebb tide glass eels, but similar to that of the other groups. Trap glass eels were significantly more pigmented than glass eels of the other groups, indicating that they were more advanced in metamorphosis. On the one hand, this may suggest that a migration delay takes place between arrival below the dam and the climbing of the eel ladder as suggested by McCleave \& Wippelhauser (1987). On the other hand, since $\mathrm{T}_{4}$ treatment accelerates pigmentation in glass eels (Vilter 1946, Jegstrup \& Rosenkilde 2003), the increased metamorphosis rate in trap glass eels was also possibly induced by increased thyroid gland activity (Fig. 5). Otolith ageing of the individuals would allow discrimination between these 2 hypotheses (Cieri \& McCleave 2001).

\section{Thyroid status parameters}

Because glass eels are too small to sample their blood, we measured (by RIA) whole-body $T_{3}$ and $T_{4}$ contents, and calculated TH content $\left(\mathrm{T}_{3}+\mathrm{T}_{4}\right)$ as well as the $T_{3}: T_{4}$ ratio. $T_{4}$ levels depend on thyroid gland production and $\mathrm{T}_{4}$ ORD activity rates. The plasma $\mathrm{T}_{4}$ level is generally considered as the most common proxy for evaluating thyroidal status (Eales \& Brown 1993). Whole-body $\mathrm{T}_{4}$ content includes the thyroid gland, blood and tissue stocks. Consequently, whole-body $\mathrm{T}_{4}$, and a fortiori $\mathrm{TH}$, may be considered reliable parameters for thyroid gland synthesis-activity.

Plasma $T_{3}$ levels depend on $T_{4}$ ORD activity and degradation rates. A complex system of deiodase pathways tend to maintain intracellular $\mathrm{T}_{3}$ tone at some set point determined by the physiologic state (Eales \& Brown 1993). In fishes, as in mammals, thyroidal status, through $\mathrm{T}_{3}$ production, may regulate energydemanding processes (Eales \& McLatchy 1989). Thus, whole-body $\mathrm{T}_{3}$ levels in glass eels was assumed to reflect the energy demand of tissues.

The plasma $T_{3}: T_{4}$ ratio reflects the $T_{4}$ ORD activity rate (Eales \& Brown 1993). In the eel, $T_{4}$ ORD activity increases with increasing temperatures and salinity (Leloup \& De Luze 1985). Temperatures were similar in all samples (12 to $14^{\circ} \mathrm{C}$ ), and salinity was only different for trap glass eels, which were sampled in freshwater. The $T_{3}: T_{4}$ ratio was not significantly different between trap and flood tide glass eels, suggesting that entry into freshwater was too recent to modify $\mathrm{T}_{4}$ ORD activity rate. Thus, we assumed that temperature and salinity did not influence $T_{3}: T_{4}$ ratio in our study, and whole-body $T_{3}: T_{4}$ was assumed to be a proxy for $T_{4}$ ORD activity.

\section{Thyroid status and its ecological interpretation}

Trap glass eels

Whole-body $\mathrm{T}_{4}$ and $\mathrm{TH}$ levels were highest in trap glass eels, indicating increased thyroid gland synthesis-activity (Figs. 4 \& 5). Trap glass eels had climbed the eel ladder and entered freshwater, a phenomenon 
corresponding to the colonization of river habitats. Hence, our results strongly suggest that the activation of the thyroid gland is related to the colonization of river habitats by Anguilla anguilla glass eels. The effects of salinity on thyroid gland synthesis-activity reported in the literature are unclear. $\mathrm{TH}$, interacting with other hormones, may be involved in acclimation to salinity (Leloup \& De Luze 1985). In the stickleback Gasterosteus aculeatus, $\mathrm{T}_{4}$ treatment induces a change in salinity preference from saltwater to freshwater (Baggerman 1962), suggesting that, in the trap glass eels, activation of the thyroid gland also induced a freshwater-seeking behavior. Young yellow eels $A$. rostrata caught climbing waterfalls with no salinity change exhibit higher plasma $\mathrm{T}_{4}$ levels than eels caught below waterfalls, but no increase in plasma $T_{3}$ levels, indicating an increased thyroid gland synthesisactivity without increased $\mathrm{T}_{4}$ ORD activity (Castonguay et al. 1990). In trap glass eels, we also monitored a sharp activation of thyroid gland coupled with no change in $T_{3}: T_{4}$ ratios. This physiological pattern was probably related to the climbing of the eel ladder, but also to the transition of behavior from the STST to the active colonization of the river, as first hypothesized by McCleave \& Wippelhauser (1987). The activation of thyroid gland synthesis-activity in trap glass eels is the result of the stimulation of the thyreotrop axis through TSH and would represent deep physiological changes in the glass eels. Further experiments are needed to investigate the temporal relationships between the activation of the thyroid gland and the triggering of transition behavior and (or) climbing behavior.

Whole-body $\mathrm{T}_{3}$ levels were significantly higher in trap than in flood tide glass eels, suggesting an increased energy demand in tissues of the former, Flood tide glass eels were caught in the water column on flood tide, probably exhibiting an STST behavior which is a flow-supported swimming behavior (Gascuel 1986). In contrast, trap glass eels had climbed the eel ladder. This behavior requires strong locomotory activity, and consequently an increased requirement for $T_{3}$ by the tissues to meet the increased energy demand. A stimulating role of $\mathrm{TH}$ on energetic metabolism during fish migration was previously reported by Woodhead (1975). Our results support this.

\section{Bottom glass eels}

Whole-body $\mathrm{T}_{4}$ and $\mathrm{TH}$ levels in bottom glass eels were the lowest of all groups and significantly lower than those of flood tide and trap glass eels, indicating decreased thyroid gland activity (Figs. $4 \& 5$ ). The bottom glass eels collected had remained on the bottom of the estuary despite the presence of a flood tide. This behavior does not correspond to that of migrating glass eels in the estuary (STST); these swim up into the water column at flood tide and are carried upstream by the current. This suggests that the bottom glass eels had switched from a migrating to a settling behavior. Our data, showing a correlation between settling behavior and decreasing thyroid gland synthesis activity, are in accordance with the experimental data of Jegstrup \& Rosenkilde (2003), who showed that glass eels Anguilla anguilla have lower whole-body $\mathrm{T}_{4}$ contents when they switch from swimming to resting on the bottom of aquaria. Consequently, our results suggest that the loss of migratory behavior in glass eels is linked to decreased thyroid gland activity.

Flood tide versus ebb tide glass eels

Whole-body TH content did not differ significantly between flood and ebb tide glass eels, and was intermediate in these 2 groups compared to that of bottom and trap glass eels (Fig. 5). Ebb tide and flood tide glass eels were both collected while swimming in the water column of the estuary, suggesting that they were exhibiting estuarine migratory behavior (STST). This may indicate that STST corresponds to a thyroid gland activity intermediate between that of rivercolonizing and that of settling glass eels. Nevertheless, despite similar TH contents, ebb tide glass eels had significantly lower $\mathrm{T}_{4}$ levels than flood tide glass eels (Fig. 4), indicating a decrease in thyroid gland secretory activity. This suggests that ebb tide glass eels were close to the switch from migratory to settling behavior.

In contrast, whole-body $\mathrm{T}_{3}$ levels were significantly higher in ebb-tide than in flood tide glass eels, suggesting an increased energy demand in the former. Ebb tide glass eels had to swim actively against the current to maintain their position below the dam against the downstream ebb, whereas flood tide glass eels were swimming with the flow. Therefore, in contrast to flood tide individuals ebb tide glass eels did not take advantage of tidal transport, nor did they seek shelter on the substrate. Their counter-current swimming behavior induced increased locomotory activity and a consequent increased energy demand of the tissues. The increased $T_{3}$ content of ebb tide individuals was sustained despite decreased thyroid gland activity, and was therefore probably related to increased $\mathrm{T}_{4}$ ORD activity.

As indicated by the $T_{3}: T_{4}$ ratios, $T_{4}$ ORD activity was significantly higher in ebb tide and bottom glass eels than in trap and flood tide glass eels. This indicates that both bottom and ebb tide glass eels have increased capacities for producing $\mathrm{T}_{3}$ from $\mathrm{T}_{4}$ com- 
pared to trap and flood tide glass eels. Through the higher affinity of $T_{3}$ rather than $T_{4}$ to $T H$ receptors, this mechanism increases the biological activity of thyroid hormones despite decreased thyroid gland synthesis-activity. It may be the consequence of physiological stress. In the eel, the growth hormone $(\mathrm{GH})$ promotes $\mathrm{T}_{4}$ ORD activity (De Luze \& Leloup 1984), and it has been shown that stress, fasting, or a low condition factor induces an increase in GH production by the pituitary gland in the yellow eel (Marchelidon et al. 1996, Rousseau et al. 1999, Dufour et al. 2001) and glass eel (Lambert et al. 2003) (present Fig. 1). Ebb tide glass eels had the lowest body masses of all groups, indicating low condition and physiological stress. Environmental conditions were similar throughout the sampling period and, as indicated by pigment stages, ebb tide glass eels spent the same amount of time in the estuary as flood tide glass eels. Hence, the physiological stress observed in ebb tide glass eels could not be the consequence of different environmental factors but was rather the result of divergent migratory behavior.

We therefore propose an ecological and physiological mechanism for the divergent migratory behavior of ebb tide glass eels. These individuals were caught in the mid water column at ebb tide, whereas glass eels using STST sought shelter on the bottom, waiting for the next flood tide. This suggests that the rhythm of the biological clock of ebb tide individuals was no longer in phase with the flood tide, inducing a non-optimal use of currents requiring frequent counter-current swimming. For juvenile fishes, STST enables an energy conservation (cost-per-unit-distance) of $>90 \%$ compared to constant swimming (Weihs 1978). Therefore, the physiological stress detected in ebb tide glass eels was presumably induced by a too high energetic expenditure during migration. The similar physiological patterns (decreased thyroid gland and increased $\mathrm{T}_{4}$ ORD activities) of bottom and ebb tide glass eels suggests that physiological stress induced by a misphased rhythm of the biological clock may lead to precocious settling behavior. This settling behavior may represent the beginning of estuarine residency, although our present data cannot exclude the possibility that the settling behavior of bottom glass eels may be only transient. If settlement leads to residency, this mechanism could explain the colonization of estuarine or marine habitats by Anguilla anguilla. We do not yet know why the rhythm of the biological clock of ebb tide glass eels becomes misphased, but suggest that the thyroid gland may play a role in the regulation of activity rhythms in glass eels.

In conclusion, our data has revealed that thyroidal status is related to the migratory behavior of glass eels.
Increased thyroid gland activity is linked to the active colonization of river habitats, and may also induce freshwater-seeking behavior. Behavioral experiments, including TH treatment, are necessary to elucidate the role of TH in triggering migratory behavior. If some individuals constantly exhibit a higher thyroid gland activity and migratory behavior than the rest of the population, this may indicate the existence of pioneer individuals (Fontaine 1975, Feunteun et al. 2003). Precocious settlement in estuarine habitats at the glass eel stage seems to involve decreased activity of the thyroid gland but increased $\mathrm{T}_{4}$ ORD activity, probably reflecting physiological stress. Therefore, as a mechanism for the loss of migratory behavior in estuaries at the glass eel stage we propose that the rhythm of the biological clock becomes misphased, preventing the glass eels from efficient use of tidal streams as transport means and inducing a physiological stress through the resultant high energetic cost of migration. This leads to the loss of the migratory behavior and consequently to settlement. Our data further reveals the role of $\mathrm{TH}$ in glass eel migration and settlement. One facet of our findings is the awareness that endocrine disruptors such as PCBs, by blocking the action of TH on receptors (Iwasaki et al. 2002), may also reduce the colonization of river habitats by glass eels.

Acknowledgements. We are grateful to Dr. R. Denver, University of Michigan, for fruitful methodological discussions. We sincerely want to thank B. Sauvaget (IAV) for his help during night sampling. P. Lambert (Cemagref) critically read the manuscript and helped us with the statistical analysis. We thank Dr. I. Mayer (University of Bergen) for English corrections. P. Camoin (Cemagref) drew Fig. 2. This work was partly supported by a research grant from GRISAM.

\section{LITERATURE CITED}

Baggerman B (1962) Some endocrine aspects of fish migration. Gen Comp Endocrinol (Suppl) 1:188-205

Bres O, Eales JG (1986) Thyroid hormone binding to isolated trout (Salmo gairdneri) liver nuclei in vitro: binding affinity, capacity, and chemical specificity. Gen Comp Endocrinol 61:29-39

Briand C, Fatin D, Legault A (2002) Role of eel odour on the efficiency of an eel, Anguilla anguilla, ladder and trap. Environ Biol Fish 65:473-477

Castonguay M, Dutil JD, Audet C, Miller R (1990) Locomotor activity and concentration of thyroid hormones in migratory and sedentary juvenile American eels. Trans Am Fish Soc 119:946-956

Cieri MD, McCleave JD (2001) Validation of daily otolith increments in glass phase american eels Anguilla rostrata (Lesueur) during estuarine residency. J Exp Mar Biol Ecol 257:219-227

Comeau LA, Campana SE, Chouinard GA, Hanson JM (2001) Timing of Atlantic cod Gadus morhua seasonal migration in relation to serum levels of gonadal and thyroidal hormones. Mar Ecol Prog Ser 221:245-253 
Creutzberg F (1961) On the orientation of migrating elvers (Anguilla vulgaris Turt.) in a tidal area. Neth J Sea Res 1: 257-338

Darling DS, Dickhoff WW, Gorbman A (1982) Comparison of thyroid hormone binding to hepatic nuclei of the rat and a teleost (Oncorhynchus kisutch). Endocrinology 111: 1936-1943

De Luze A, Leloup J (1984) Fish growth hormone enhances peripheral conversion of thyroxine to triiodothyronine in the eel (Anguilla anguilla L.). Gen Comp Endocrinol 56:308-312

Denver RJ (1993) Acceleration of anuran amphibian metamorphosis by corticotropin-releasing hormone-like peptides. Gen Comp Endocrinol 91:38-51

Dufour S, Rousseau K, Sbaihi M, Le Belle N, Vidal B, Marchelidon J, Schmitz M (2001) Multiple neuroendocrine regulation of growth hormone in the European eel Anguilla anguilla. J Taiwan Fish Res 9:77-92

Eales JG (1979) Thyroid functions in cyclostomes and fishes. In: Barrington EJW (ed) Hormones and evolution. Academic Press, London, p 341-436

Eales JG, Brown SB (1993) Measurement and regulation of thyroidal status in teleost fish. Rev Fish Biol Fish 3: 199-347

Eales JG, McLatchy DL (1989) The relationship between $T_{3}$ production and energy balance in salmonids and other teleosts. Fish Physiol Biochem 7:289-293

Elie P (1979) Contribution à l'étude des montées de civelles d'Anguilla anguilla Linné (Poisson, Téléostéen, Anguilliforme), dans l'estuaire de la Loire: pêche, écologie, écophysiologie et élevage. PhD thesis, Rennes 1 University, Rennes

Elie P, Lecomte-Finiger R, Cantrelle I, Charlon N (1982) Définition des limites des différents stades pigmentaires durant la phase civelle d'Anguilla anguilla L. (poisson téléostéen anguilliforme). Vie Milieu 32:149-157

Feunteun E, Laffaille P, Robinet T, Briand C, Baisez A, Olivier JM, Acou A (2003) A review of upstream migration and movements in inland waters by anguillid eels. Towards a general theory. In: Aida K, Tsukamoto K, Yamauchi K (eds) Eel biology. Springer-Verlag, Tokyo, p 191-213

Fontaine M (1975) Physiological mechanisms in the migration of marine and amphihaline fish. Adv Mar Biol 13:241-355

Fontaine M, Callamand O (1941) Sur l'hydrotropisme des civelles. Bull Inst Océanogr 811:1-6

Gascuel D (1986) Flow carried and active swimming migration of the glass eel (Anguilla anguilla) in the tidal area of a small estuary on the French Atlantic coast. Helgol Meeresunters 40:321-326

Greenblatt M, Brown CL, Lee M, Dauder S, Bern HA (1989) Changes in thyroid hormone levels in eggs and larvae and in iodine uptake by eggs of coho and chinook salmon, Oncorhynchus kisutsch and O. tschawytscha. Fish Physiol Biochem 6:261-278

Hirata Y, Kurokura H, Kasahara S (1989) Effects of thyroxine and thiourea on the development of larval red sea bream Pagrus major. Nippon Suisan Gakkaishi 55:1189-1195

Iwasaki T, Miyazaki W, Takeshita A, Kuroda Y, Koibuchi N (2002) Polychlorinated biphenyls suppress thyroid hormone-induced transactivation. Biochem Biophys Res Commun 299:384-388

Iwata M (1995) Downstream migratory behavior of salmonids and its relationship with cortisol and thyroid hormones: a review. Aquaculture 135:131-139

Iwata $M$, Tsuboi $H$, Yamashita $T$, Amemiya A, Yamada $H$, Chiba H (2003) Function and trigger of thyroxine surge in migrating chum salmon Oncorhynchus keta fry. Aquaculture 222:315-329
Jegstrup IM, Rosenkilde P (2003) Regulation of post-larval development in the European eel: thyroid hormone level, progress of pigmentation and changes in behaviour. J Fish Biol 63:168-175

Jellyman DJ, Lambert PW (2003) Factors affecting recruitment of glass eels into the Grey River, New Zealand. J Fish Biol 63:1067-1079

Lambert P, Sbaihi M, Rochard E, Marchelidon J, Dufour S, Elie P (2003) Variabilités morphologique et du taux d'hormone de croissance des civelles d'anguilles européennes (Anguilla anguilla) dans l'estuaire de la Gironde au cours de la saison 1997-1998. Bull Fr Pêche Piscic 368:69-84

Legault A (1992) Etude de quelques facteurs de sélectivité de passes à anguilles. Bull Fr Pêche Piscic 325:83-91

Leloup J, De Luze A (1985) Environmental effects of temperature and salinity on thyroid function in teleost fishes. In: Follet BK, Ishii S, Chandola A (eds) The endocrine system and the environment. Springer-Verlag, Berlin, p 23-32

Marchelidon J, Schmitz M, Houdebine LM, Vidal B, Le Belle N, Dufour S (1996) Development of a radioimmunoassay for European eel growth hormone and application to the study of silvering and experimental fasting. Gen Comp Endocrinol 102:360-369

McCleave JD, Kleckner RC (1982) Selective tidal stream transport in the estuarine migration of glass eels of the American eel (Anguilla rostrata). J Cons Int Explor Mer 40: 262-271

McCleave JD, Wippelhauser GS (1987) Behavioural aspects of selective tidal stream transport in juvenile American eels. Am Fish Soc Symp 1:138-150

Metcalfe JD, Arnold GP, Webb PW (1990) The energetics of migration by selective tidal stream transport: an analysis for plaice tracked in the southern North Sea. J Mar Biol Assoc UK 70:149-162

Rousseau K, Le Belle N, Marchelidon J, Dufour S (1999) Evidence that corticotropin-releasing hormone acts as a growth hormone-releasing factor in a primitive teleost, the European eel (Anguilla anguilla). J Neuroendocrinol 11: 385-392

Schmidt J (1909) Remarks on the metamorphosis and distribution of the larvae of the eel. Medd Komm Havunders Ser Fiskeri 3:1-17

Schreiber AM, Specker JL (1999) Early larval development and metamorphosis in the summer flounder: changes in per cent whole-body water content and effects of altered thyroid status. J Fish Biol 55:148-157

Silberschneider V, Pease BC, Booth DJ (2001) A novel artificial habitat collection device for studying resettlement patterns in anguillid glass eels. J Fish Biol 58:1369-1370

Specker JL, Eales JG, Tagawa M, Tyler WA III (2000) Parrsmolt transformation in Atlantic salmon: thyroid deiodination in liver and brain and endocrine correlates of change in rheotactic behavior. Can J Zool 78:696-705

Tabeta O, Mochioka N (2003) The glass eel. In: Aida K, Tsukamoto K, Yamauchi K (eds) Eel biology. SpringerVerlag, Tokyo, p 75-87

Tagawa M, Hirano T (1987) Presence of thyroxine in eggs and changes in its content during early development of chum salmon, Oncorhynchus keta. Gen Comp Endocrinol 68: 129-135

Tsukamoto K, Arai T (2001) Facultative catadromy of the eel Anguilla japonica between freshwater and seawater habitats. Mar Ecol Prog Ser 220:265-276

Tzeng WN, Lizuka Y, Shiao JC, Yamada Y, Oka HP (2003) Identification and growth rates comparison of divergent migratory contingents of Japanese eel (Anguilla japonica). Aquaculture 216:77-86 
Vilter V (1946) Action de la thyroxine sur la métamorphose larvaire de l'anguille. C R Séances Soc Biol 140: 783-785

Weihs D (1978) Tidal stream transport as an efficient method for migration. J Cons Int Explor Mer 38:92-99

Wippelhauser GS, McCleave JD (1987) Precision of behavior of migrating juvenile American eels (Anguilla rostrata) utilizing selective tidal stream transport. J Cons Perm Int Explor Mer 44:80-89

Editorial responsibility: Otto Kinne (Editor),

Oldendorf/Luhe, Germany
Wippelhauser GS, McCleave JD (1988) Rhythmic activity of migrating juvenile American eels Anguilla rostrata. J Mar Biol Assoc UK 68:81-91

Woodhead AD (1975) Endocrine physiology of fish migration. Oceanogr Mar Biol Annu Rev 13:287-382

Yamano K, Tagawa M, Dejesus EG, Hirano T, Miwa S, Inui Y (1991) Changes in whole-body concentrations of thyroidhormones and cortisol in metamorphosing conger eel. J Comp Physiol B 161:371-375

Submitted: March 4, 2004; Accepted: July 4, 2004

Proofs received from author(s): October 29, 2004 